\title{
Leaching of Pure Chalcocite in a Chloride Media Using Sea Water and Waste Water
}

\author{
Norman Toro ${ }^{1,2, *}$, Williams Briceño ${ }^{3}$, Kevin Pérez ${ }^{1}\left(\mathbb{D}\right.$, Manuel Cánovas $^{1}\left[{ }^{\circledR}\right.$, Emilio Trigueros $^{2}$, \\ Rossana Sepúlveda 4 (D) and Pía Hernández ${ }^{5}$ (D) \\ 1 Departamento de Ingeniería en Metalurgia y Minas, Universidad Católica del Norte, Av. Angamos 610, \\ Antofagasta 1270709, Chile \\ 2 Department of Mining, Geological and Cartographic Department, Universidad Politécnica de Cartagena, \\ Paseo Alfonso X111 N52, 30203 Cartagena, Spain \\ 3 Departamento de Ingeniería Industrial, Universidad Católica del Norte, Av. Angamos 610, \\ Antofagasta 1270709, Chile \\ 4 Departamento de Ingeniería en Metalurgia, Universidad de Atacama, Av. Copayapu 485, \\ Copiapó 1531772, Chile \\ 5 Departamento de Ingeniería Química y Procesos de Minerales, Universidad de Antofagasta, \\ Avda. Angamos 601, Antofagasta 1240000, Chile \\ * Correspondence: ntoro@ucn.cl; Tel.: +56-552651021
}

Received: 25 June 2019; Accepted: 11 July 2019; Published: 12 July 2019

\begin{abstract}
Chalcocite is the most important and abundant secondary copper ore in the world with a rapid dissolution of copper in an acid-chloride environment. In this investigation, the methodology of surface optimization will be applied to evaluate the effect of three independent variables (time, concentration of sulfuric acid and chloride concentration) in the leaching of pure chalcocite to extract the copper with the objective of obtaining a quadratic model that allows us to predict the extraction of copper. The kinetics of copper dissolution in regard to the function of temperature is also analyzed. An ANOVA indicates that the linear variables with the greatest influence are time and the chloride concentration. Also, the concentration of chloride-time exerts a significant synergic effect in the quadratic model. The ANOVA indicates that the quadratic model is representative and the $\mathrm{R}^{2}$ value of 0.92 is valid. The highest copper extraction $(67.75 \%)$ was obtained at $48 \mathrm{~h}$ leaching under conditions of $2 \mathrm{~mol} / \mathrm{L} \mathrm{H}_{2} \mathrm{SO}_{4}$ and $100 \mathrm{~g} / \mathrm{L}$ chloride. The XRD analysis shows the formation of a stable and non-polluting residue; such as elemental sulfur $\left(\mathrm{S}^{0}\right)$. This residue was obtained in a leaching time of $4 \mathrm{~h}$ at room temperature under conditions of $0.5 \mathrm{~mol} / \mathrm{L} \mathrm{H}_{2} \mathrm{SO}_{4}$ and $50 \mathrm{~g} / \mathrm{L} \mathrm{Cl}^{-}$.
\end{abstract}

Keywords: chalcocite; sulphide leaching; copper; reusing water; desalination residue; ecological treatment

\section{Introduction}

Most of the copper minerals on the planet correspond to sulfur minerals and a smaller amount of oxidized minerals. A report by COCHILCO [1] mentions that the world copper production is currently 19.7 million tons. Seventy-five percent of this total comes from the pyrometallurgical processing of copper sulfide minerals processed in smelting plants [2], and $25 \%$ by the hydrometallurgical route [3].

There is a need to generate a new momentum that overcomes a certain stagnation in the growth capacity of the mining industry. Even in its role as a surplus generator, large-scale mining faces great challenges. These include an increase in costs due to various factors; such as the deterioration of laws and other elements associated with the aging of deposits and input costs to be compatible with sustainable development demands [4]. 
Sulfur minerals have been treated for decades with flotation and pyrometallurgical processes [5], which result in major environmental problems; such as tailings dams and the generation of acid drainage (sulfuric acid and oxides of iron) by the oxidation of sulfur minerals with a high presence of pyrite. This sulfide is one of the most common and abundant minerals in the world and is associated with hydrothermal mineralization [6]. On the other hand, foundries produce large emissions of sulfur dioxide $\left(\mathrm{SO}_{2}\right)$, which together, with $\mathrm{NO}_{x}$ and $\mathrm{CO}_{2}$, can cause large problems; such as acid rain and increasing local pollution, therefore, the abatement of waste gases is an important task for the protection of the environment [7-9]. As a result, new hydrometallurgical alternatives are being developed in the mining industry, because they are more ecological and economic processes to recover copper $[10,11]$.

Chalcocite is the most abundant copper sulfide mineral after chalcopyrite [5,12], and it is the copper sulfide the most easily treated by hydrometallurgical routes [13]. Several investigations have been carried out for the leaching of this mineral with the use of multiple additives and in different media such as; bioleaching [14-18], ferric sulfate solution [19], chloride media [20-23], pressure leaching for chalcocite [24] and synthetic chalcocite (white metal) [25].

When operating in sulphated or chloride media, the oxidative dissolution of the chalcocite occurs in two stages $[13,19,20,23,25]$.

$$
\begin{gathered}
\mathrm{Cu}_{2} \mathrm{~S}+2 \mathrm{Fe}^{3+}=\mathrm{Cu}^{2+}+2 \mathrm{Fe}^{2+}+\mathrm{CuS} \\
\mathrm{CuS}+2 \mathrm{Fe}^{3+}=\mathrm{Cu}^{2+}+2 \mathrm{Fe}^{2+}+\mathrm{S}^{0}
\end{gathered}
$$

The first stage of leaching of the chalcocite is much faster than the second stage. This is controlled by diffusion of the oxidant on the surface of the ore at low values of activation energy $\left(4-25 \mathrm{~kJ} \mathrm{~mol}^{-1}\right)$ [19]. The second stage is slower and can be accelerated depending on the temperature $[13,26]$.

The investigations shown in Table 1 were obtained as a result of high extractions (90\%), but these results were obtained with the application of high temperatures and/or with the addition of ferric or cupric ions as an oxidizing agent. In addition, the previous investigations were made with mixtures of copper sulfides, with the presence of gangue or with the use of synthetic chalcocite. It is emphasized that the present investigation will include a leaching of pure chalcocite in a chlorinated medium, without the addition of oxidizing agents $\left(\mathrm{Fe}^{3+}, \mathrm{Cu}^{2+}\right.$, etc.) and at room temperature.

\begin{tabular}{|c|c|c|c|c|}
\hline Investigation & $\begin{array}{c}\text { Leaching } \\
\text { Agent }\end{array}$ & Parameters Evaluated & Reference & Cu Ext (\%) \\
\hline $\begin{array}{c}\text { The kinetics of leaching } \\
\text { chalcocite (synthetic) in acidic } \\
\text { oxygenated } \\
\text { sulphate-chloride solutions }\end{array}$ & $\begin{array}{c}\mathrm{NaCl} \\
\mathrm{H}_{2} \mathrm{SO}_{4} \\
\mathrm{HCl}, \mathrm{HNO}_{3} \\
\text { and } \mathrm{Fe}^{3+}\end{array}$ & $\begin{array}{l}\text { Oxygen flow, stirring speed, } \\
\text { temperature, sulfuric acid } \\
\text { concentration, ferric ions } \\
\text { concentration, chloride } \\
\text { concentration and particle size. }\end{array}$ & {$[20]$} & 97 \\
\hline $\begin{array}{l}\text { The kinetics of dissolution of } \\
\text { synthetic covellite, chalcocite } \\
\text { and digenite in dilute chloride } \\
\text { solutions at } \\
\text { ambient temperatures }\end{array}$ & $\begin{array}{l}\mathrm{HCl}, \mathrm{Cu}^{2+} \\
\text { and } \mathrm{Fe}^{3+}\end{array}$ & $\begin{array}{l}\text { Potential effect, chloride } \\
\text { concentration, acid concentration, } \\
\text { temperature, dissolved oxygen } \\
\text { and pyrite effect. }\end{array}$ & [13] & 98 \\
\hline $\begin{array}{l}\text { Leaching kinetics of digenite } \\
\text { concentrate in oxygenated } \\
\text { chloride media at } \\
\text { ambient pressure }\end{array}$ & $\begin{array}{c}\mathrm{CuCl}_{2}, \mathrm{HCl} \\
\text { and } \mathrm{NaCl}\end{array}$ & $\begin{array}{l}\text { Effect of stirring speed, oxygen } \\
\text { flow, cupric ion concentration, } \\
\text { chloride concentration, acid } \\
\text { concentration and } \\
\text { temperature effect. }\end{array}$ & [27] & 95 \\
\hline $\begin{array}{l}\text { Leaching of sulfide copper ore } \\
\text { in a } \mathrm{NaCl}-\mathrm{H}_{2} \mathrm{SO}_{4}-\mathrm{O}_{2} \text { media } \\
\text { with acid pre-treatment }\end{array}$ & $\begin{array}{c}\mathrm{NaCl} \text { and } \\
\mathrm{H}_{2} \mathrm{SO}_{4}\end{array}$ & $\begin{array}{l}\text { Chloride concentration, effect of } \\
\text { agitation with compressed air, } \\
\text { percentage of solids and } \\
\text { particle size. }\end{array}$ & {$[22]$} & 78 \\
\hline
\end{tabular}

Table 1. Comparison of previous investigations of chalcocite with the use of $\mathrm{Cl}^{-}$. 
A chalcocite leaching is performed with the injection of $\mathrm{O}_{2}$ at ambient pressure in a $\mathrm{H}_{2} \mathrm{SO}_{4}-\mathrm{NaCl}$ solution, where the leaching agents are $\mathrm{Cu}^{2+}, \mathrm{CuCl}^{+}, \mathrm{CuCl}_{2}$ and $\mathrm{CuCl}_{3}^{-}$, which are generated during leaching in a $\mathrm{Cu}^{2+} / \mathrm{Cl}^{-}$system. The general reaction of chalcocite leaching is as follows:

$$
\mathrm{Cu}_{2} \mathrm{~S}+0.5 \mathrm{O}_{2}+2 \mathrm{H}^{+}+4 \mathrm{Cl}^{-}=2 \mathrm{CuCl}_{2}^{-}+\mathrm{H}_{2} \mathrm{O}+\mathrm{S}^{0}
$$

While the chalcocite leaching reactions occur in two stages, guiding us to Equation (3), the following occurs:

$$
\begin{gathered}
\mathrm{Cu}_{2} \mathrm{~S}+2 \mathrm{Cl}^{-}+\mathrm{H}^{+}+0.25 \mathrm{O}_{2}=\mathrm{CuCl}_{2}^{-}+\mathrm{CuS}+0.5 \mathrm{H}_{2} \mathrm{O}, \\
\mathrm{CuS}+2 \mathrm{Cl}^{-}+\mathrm{H}^{+}+0.25 \mathrm{O}_{2}=0.5 \mathrm{H}_{2} \mathrm{O}+\mathrm{CuCl}_{2}^{-}+\mathrm{S}^{0},
\end{gathered}
$$

The resulting products expected from this chalcocite leaching should be soluble copper; such as $\mathrm{CuCl}_{2}^{-}$and a solid residue of elemental sulfur $\left(\mathrm{S}^{0}\right)$ with covellite residues or copper polysulfides $\left(\mathrm{CuS}_{2}\right)$ that still contain valuable metals.

The $\mathrm{CuCl}_{2}^{-}$is the predominant soluble specie due to the complexation of $\mathrm{Cu}$ (I) with the presence of $\mathrm{Cl}^{-}$at room temperature, in a system of high concentrations of chloride (greater than $1 \mathrm{M}$ ). This $\mathrm{CuCl}_{2}^{-}$is stable in a range of potentials between $0-500 \mathrm{mV}$ and $\mathrm{pH}<6-7$ (depending on the chloride concentration in the system) [20,28].

The shortage of fresh water in arid areas is an economic, environmental and social problem [29]. The use of sea water has become increasingly important for mining in Chile, not only because of its positive effects on leaching processes due to its chloride content, but also as a strategic and indispensable resource. For example, some metallic and non-metallic mining companies in the north of Chile have deposits rich in copper, gold, silver, iron and minerals from salt lakes, which are found in hyper-arid zones and at high altitudes, which emphasizes the necessity of this resource [30]. In addition, it is important to mention that the Chilean authorities have indicated that large-scale mining projects involving the use of water from aquifers will not be authorized [31]. An attractive alternative is the use of waste water from desalination plants. These companies produce drinking water for the population, however, their disposal product pollutes the oceans, for this reason, it is necessary to think of possible alternatives to recycle this resource and at the same time optimize extraction processes in local mining.

In the present investigation, a statistical analysis will be carried out using the methodology of surface optimization (design of the central composite face) to sensitize independent parameters (time, sulfuric acid concentration and chloride concentration) in the leaching of a pure mineral of chalcocite in chlorinated media. In addition, the effect on chloride concentration in the system will be evaluated when operating with potable water, seawater and reusing waste water.

\section{Materials and Methods}

\subsection{Chalcocite}

The pure chalcocite mineral used for the present investigation was collected manually directly from the veins by expert geologists from Mina Atómica, located in the region of Antofagasta, Chile.

The pure chalcocite samples were checked by X-ray diffraction (XRD) analysis, using an automatic and computerized X-ray diffractometer Bruker model Advance D8 (Bruker, Billerica, MA, USA). Figure 1 shows the results of the XRD analysis, indicating the presence of $99.9 \%$ chalcocite. The chemical analysis was performed by atomic emission spectrometry via induction-coupled plasma (ICP-AES), the sample of chalcocite was digested using aqua regia and HF. Table 2 shows the chemical composition of the samples. The samples for XRD and ICP-OES were ground in a porcelain mortar to reach a size range between $-147+104 \mu \mathrm{m}$. The procedures described were performed in the applied geochemistry laboratory of the department of geological sciences of the Universidad Católica del Norte. 


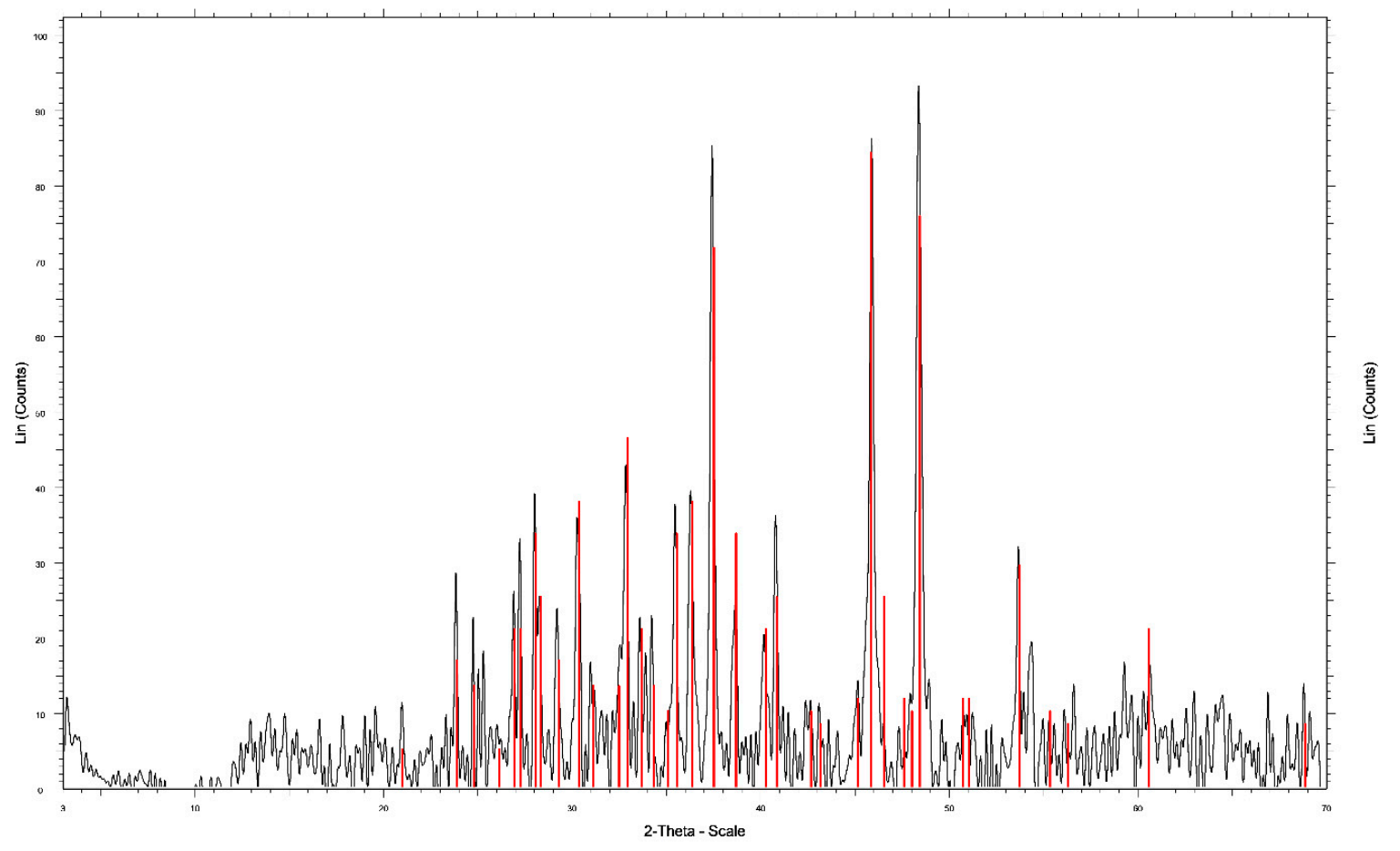

Figure 1. X-ray diffractogram for the chalcocite mineral.

Table 2. Chemical analysis of the chalcocite ore.

\begin{tabular}{ccc}
\hline Component & $\mathbf{C u}$ & $\mathbf{S}^{\mathbf{0}}$ \\
\hline Mass $(\%)$ & 79.83 & 20.17 \\
\hline
\end{tabular}

\subsection{Leaching and Leaching Tests}

The sulfuric acid used for the leaching tests was grade P.A., Merck brand, purity $95-97 \%$, density $1.84 \mathrm{~kg} / \mathrm{L}$ and molecular weight of $98.08 \mathrm{~g} / \mathrm{mol}$, though the tests also work with the use of sea water and waste water from the "Aguas Antofagasta" Desalination Plant. Table 3 shows the chemical composition of waste water.

Table 3. Chemical analysis of waste water.

\begin{tabular}{cc}
\hline Compound & Concentration $(\mathrm{g} / \mathrm{L})$ \\
\hline Fluorine $\left(\mathrm{F}^{-}\right)$ & 0.01 \\
Calcium $\left(\mathrm{Ca}^{2+}\right)$ & 0.80 \\
Magnesium $\left(\mathrm{Mg}^{2+}\right)$ & 2.65 \\
Bicarbonate $\left(\mathrm{HCO}_{3}{ }^{-}\right)$ & 1.10 \\
Chloride $\left(\mathrm{Cl}^{-}\right)$ & 39.16 \\
Calcium carbonate $\left(\mathrm{CaCO}_{3}\right)$ & 13.00 \\
\hline
\end{tabular}

Leaching tests were carried out in a $50 \mathrm{~mL}$ glass reactor with a $0.01 \mathrm{~S} / \mathrm{L}$ ratio. A total of $200 \mathrm{mg}$ of chalcocite ore in a size range between $-147+104 \mu \mathrm{m}$ and the addition of $\mathrm{NaCl}$ at different concentrations were maintained in agitation and suspension with the use of a 5-position magnetic stirrer (IKA ROS, CEP 13087-534, Campinas, Brazil) at a speed of $600 \mathrm{rpm}$ and the temperature was controlled using an oil-heated circulator (Julabo, St. Louis, MO, USA). The temperature range tested in the experiments was $25^{\circ} \mathrm{C}$. Also, the tests were performed in duplicate and measurements (or analyzes) were carried out on $5 \mathrm{~mL}$ aliquot and diluted to a range of dilutions using atomic absorption spectrometry with a coefficient of variation $\leq 5 \%$ and a relative error between 5 to $10 \%$. Measurements of $\mathrm{pH}$ and oxidation-reduction potential (ORP) of leach solutions were made using a pH-ORP meter (HANNA HI-4222, St. Louis, MO, 
USA). The ORP solution was measured in a combination ORP electrode cell of a platinum working electrode and a saturated $\mathrm{Ag} / \mathrm{AgCl}$ reference electrode.

\subsection{Experimental Design}

The effects of independent variables on $\mathrm{Cu}$ extraction rates from leaching of chalcocite were studied using the response surface optimization method [32-35]. The central composite face (CCF) design and a quadratic model were applied to the experimental design for $\mathrm{Cu}_{2} \mathrm{~S}$ leaching.

Twenty-seven experimental tests were carried out to study the effects of time, chloride and $\mathrm{H}_{2} \mathrm{SO}_{4}$ concentration as independent variables. Minitab 18 software (version 18, Pennsylvania State University, State College, PA, USA) was used for modeling and experimental design, which allowed the study of the linear and quadratic effects of the independent variables. The experimental data were fitted by multiple linear regression analysis to a quadratic model, considering only those factors that helped to explain the variability of the model. The empirical model contains coefficients of linear, quadratic, and two-factor interaction effects.

The general form of the experimental model is represented by:

$$
\begin{aligned}
& Y=(\text { overall constant })+(\text { linear effects })+(\text { interaction effects })+(\text { curvature effects }), \\
& Y=b_{0}+b_{1} x_{1}+b_{2} x_{2}+b_{3} x_{3}+b_{12} x_{1} x_{2}+b_{13} x_{1} x_{3}+b_{23} x_{2} x_{3}+b_{11} x_{1}^{2}+b_{22} x_{2}^{2}+b_{33} x_{3}^{2}
\end{aligned}
$$

Where, $x_{1}$ is time, $x_{2}$ is Chloride, $x_{3}$ is $\mathrm{H}_{2} \mathrm{SO}_{4}$ concentration, and $b$ is the variable coefficients.

Table 4 presents the ranges of parameter values used in the experimental model. The variable values are codified in the model. The following Equation (8) is used for transforming a real value $\left(Z_{i}\right)$ into a code value $\left(X_{i}\right)$ according to the experimental design:

$$
X_{i}=\frac{Z_{i}-\frac{Z_{\text {high }}+Z_{\text {low }}}{2}}{\frac{Z_{\text {high }}-Z_{\text {low }}}{2}},
$$

$Z_{\text {high }}$ and $Z_{\text {low }}$ are the highest and lowest levels of a variable, respectively [36].

Table 4. Experimental parameters for the central design of the composite face.

\begin{tabular}{cccc}
\hline Experimental Parameters & Low & Medium & High \\
\hline $\begin{array}{c}\text { Time }(\mathrm{h}) \\
\text { Concentration } \\
\mathrm{Cl}^{-}(\mathrm{g} / \mathrm{L})\end{array}$ & 4 & 8 & 12 \\
$\mathrm{Concentration}_{\mathrm{H}_{2} \mathrm{SO}_{4}(\mathrm{~mol} / \mathrm{L})}$ & 0.5 & 50 & 100 \\
$\mathrm{Codifications}$ & -1 & 0 & 2 \\
\hline
\end{tabular}

A factorial design was applied involving three factors, each one having three levels thus 27 experimental tests were carried out in Table 5, evaluating the effect of time and $\mathrm{H}_{2} \mathrm{SO}_{4}$ and chloride concentration.

The statistical $R^{2}, R^{2}$ adj, p-values and Mallows's $C p$ indicate whether the model obtained is adequate to describe $\mathrm{Cu}$ extraction under a given domain. The $\mathrm{R}^{2}$ coefficient is a measure of the goodness of fit, which measures the proportion of total variability of the dependent variable with respect to its mean, which is explained by the regression model. The p-values represent statistical significance, which indicates whether there is a statistically significant association between the response variable and the terms. The predicted $\mathrm{R}^{2}$ was used to determine how well the model predicts the response for new observations. Finally, Mallows's $\mathrm{Cp}$ is a precise measure in the model, estimating the true parameter regression [36]. 
Table 5. Experimental configuration and Cu extraction.

\begin{tabular}{ccccc}
\hline Exp. No. & Time $\mathbf{( h )}$ & $\mathbf{C l}^{-} \mathbf{( g / L )}$ & $\mathbf{H}_{\mathbf{2}} \mathbf{S O}_{\mathbf{4}} \mathbf{( \mathbf { m o l } / \mathbf { L } )}$ & $\mathbf{C u}$ Ext. (\%) \\
\hline 1 & 4 & 20 & 0.5 & 31.63 \\
2 & 4 & 20 & 1 & 33.25 \\
3 & 4 & 20 & 2 & 37.00 \\
4 & 4 & 50 & 0.5 & 32.25 \\
5 & 4 & 50 & 1 & 33.38 \\
6 & 4 & 50 & 2 & 38.00 \\
7 & 4 & 100 & 0.5 & 44.75 \\
8 & 4 & 100 & 1 & 44.88 \\
9 & 4 & 100 & 2 & 46.19 \\
10 & 8 & 20 & 0.5 & 35.75 \\
11 & 8 & 20 & 1 & 38.75 \\
12 & 8 & 20 & 2 & 43.00 \\
13 & 8 & 50 & 0.5 & 48.13 \\
14 & 8 & 50 & 1 & 49.50 \\
15 & 8 & 50 & 2 & 50.63 \\
16 & 8 & 100 & 0.5 & 51.50 \\
17 & 8 & 100 & 1 & 53.00 \\
18 & 8 & 100 & 2 & 54.88 \\
19 & 12 & 20 & 0.5 & 52.25 \\
20 & 12 & 20 & 1 & 52.75 \\
21 & 12 & 20 & 2 & 52.63 \\
22 & 12 & 50 & 0.5 & 53.13 \\
23 & 12 & 50 & 1 & 53.13 \\
24 & 12 & 50 & 2 & 53.00 \\
25 & 12 & 100 & 0.5 & 53.25 \\
26 & 12 & 100 & 1 & 55.63 \\
27 & 12 & 100 & &
\end{tabular}

\section{Results}

\subsection{ANOVA}

An ANOVA analysis (Table 6) showed F-value and p-value for the model.

Table 6. ANOVA (analysis of variance) Cu extraction.

\begin{tabular}{ccc}
\hline Source & F-Value & p-Value \\
\hline Regression & 22.73 & 0 \\
Time & 123.15 & 0 \\
$\mathrm{Cl}^{-}$ & 45.25 & 0 \\
$\mathrm{H}_{2} \mathrm{SO}_{4}$ & 5.44 & 0.03 \\
Time $\times$ Time & 2.06 & 0.17 \\
$\mathrm{Cl}^{-} \times \mathrm{Cl}^{-}$ & 0.13 & 0.72 \\
$\mathrm{H}_{2} \mathrm{SO}_{4} \times \mathrm{H}_{2} \mathrm{SO}_{4}$ & 0.00 & 0.97 \\
Time $\times \mathrm{Cl}^{-}$ & 10.27 & 0.01 \\
${\text {Time } \times \mathrm{H}_{2} \mathrm{SO}_{4}}_{\mathrm{Cl}^{-} \times \mathrm{H}_{2} \mathrm{SO}_{4}}^{1.18}$ & 0.29 \\
\hline
\end{tabular}

In the contour plot in Figure 2, it is observed that $\mathrm{Cu}$ extraction increases at long times, high chloride concentration, and high $\mathrm{H}_{2} \mathrm{SO}_{4}$ concentration. 


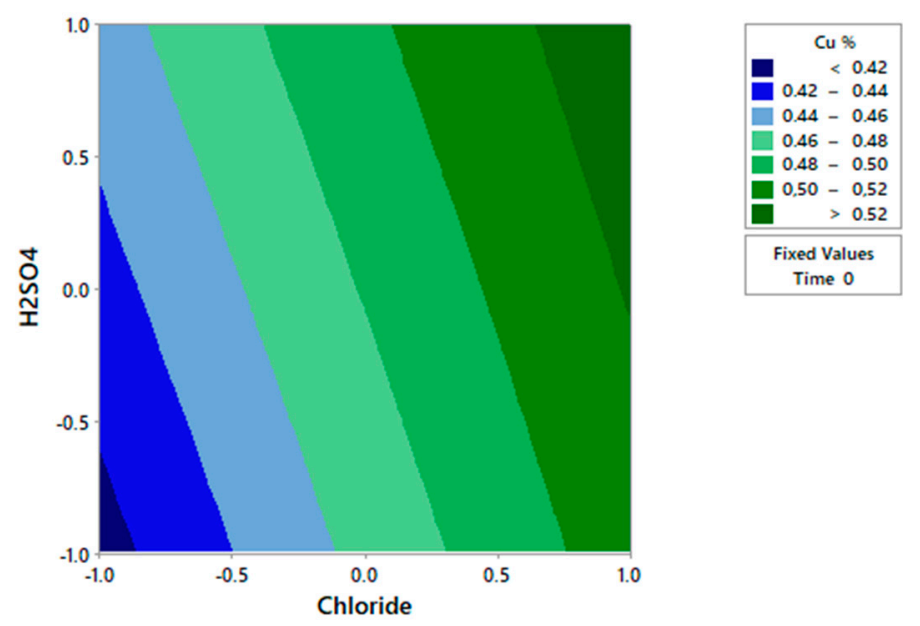

(a)

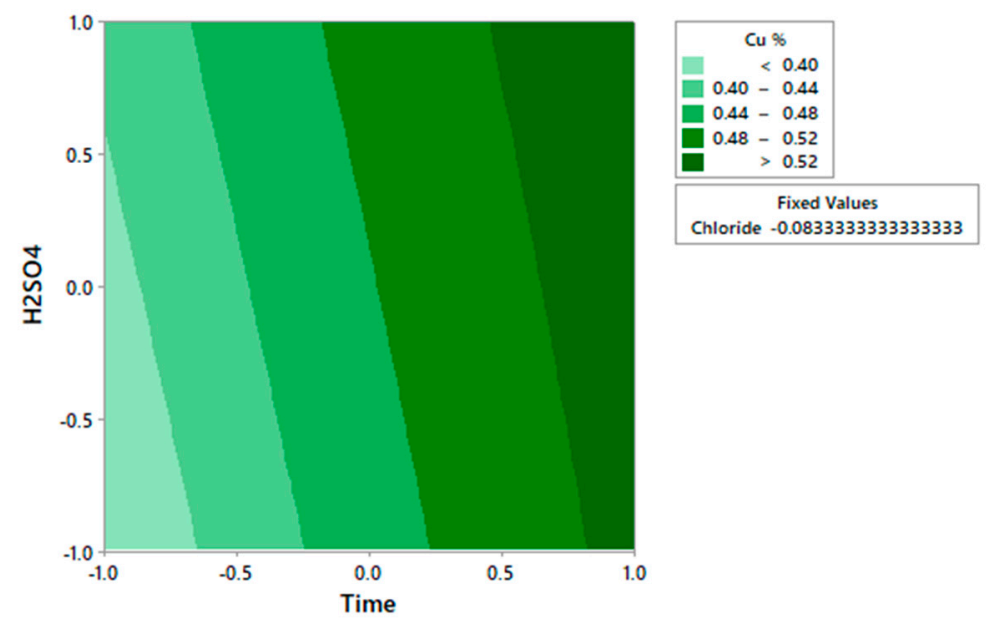

(b)

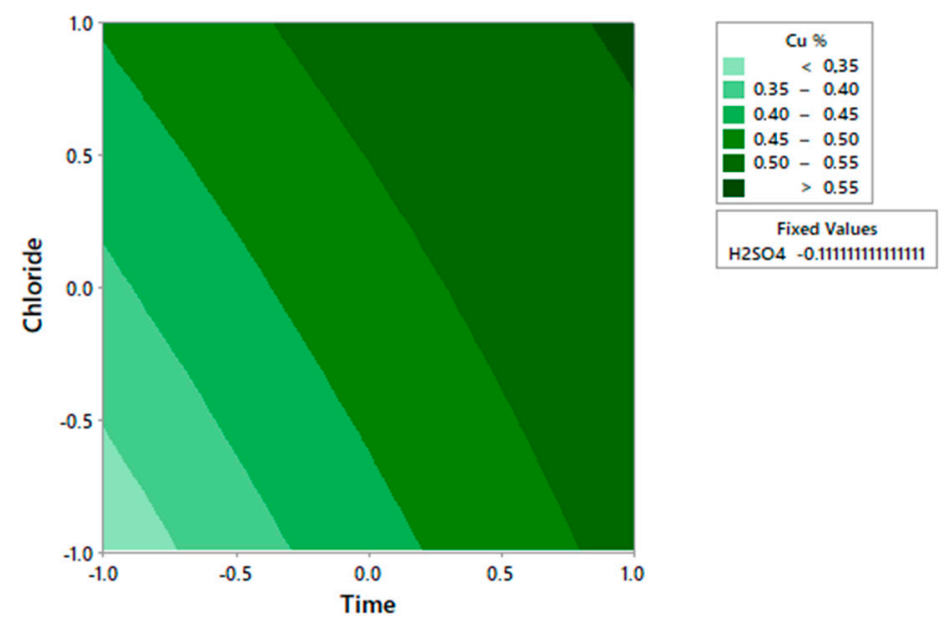

(c)

Figure 2. Experimental contour plot of independent variables of Chloride and $\mathrm{H}_{2} \mathrm{SO}_{4}$ concentration (a); Time and $\mathrm{H}_{2} \mathrm{SO}_{4}$ concentration (b); and Time and Chloride concentration (c) on the dependent variable $\mathrm{Cu}$ extraction.

Table 6 shows ANOVA analysis. There is no significant effect $(p>0.05)$ of the interactions concentration of chloride concentration of $\mathrm{H}_{2} \mathrm{SO}_{4}$ and time-concentration of $\mathrm{H}_{2} \mathrm{SO}_{4}$ in copper extraction, complying with the theory that the increase in sulfuric acid concentration does not have a great influence 
on the leaching of chalcocite above $0.02 \mathrm{~mol} / \mathrm{L}[19,22]$. Rather, it is only the time-concentration interaction of chloride that must be considered in the model. Additionally, the effects of curvature of the variable chloride concentration and $\mathrm{H}_{2} \mathrm{SO}_{4}$ concentration do not contribute significantly to explaining the variability of the model. On the other hand, the linear effects of chloride time and concentration contribute to explaining the experimental model, as shown in the contour plot of Figure 2.

Figures 3 and 4 show that time, chloride and $\mathrm{H}_{2} \mathrm{SO}_{4}$ concentration, as well as the interaction of time- $\mathrm{H}_{2} \mathrm{SO}_{4}$ and $\mathrm{Cl}-\mathrm{H}_{2} \mathrm{SO}_{4}$ affected $\mathrm{Cu}$ extraction.

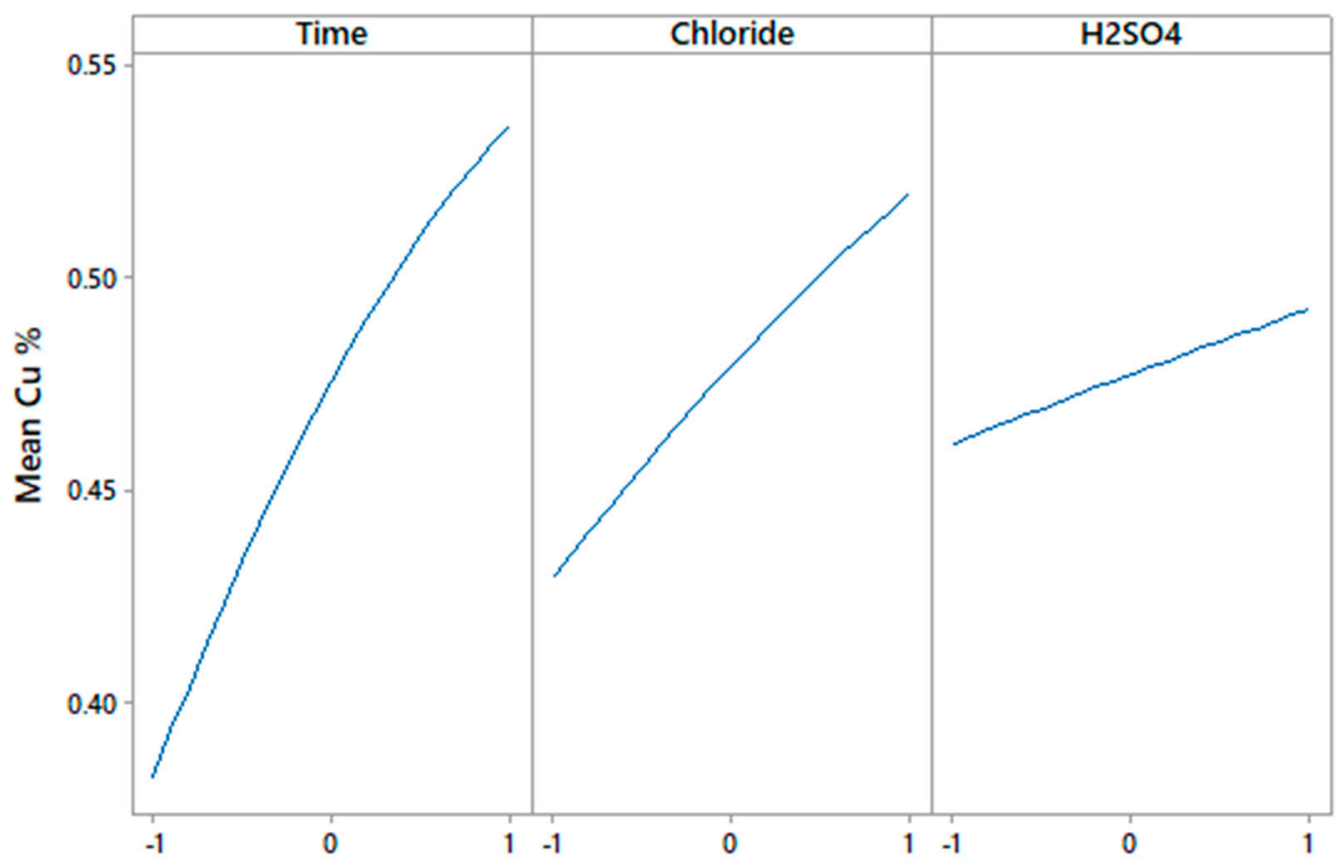

Figure 3. Linear effect plot for Cu extraction.

In Figure 3, the linear effects demonstrate what has been said by several authors [13,20,37], with respect to the effect of the concentration of chloride present in the leaching media and the effect of sulfuric acid concentration. The concentration of chloride has a great impact on the dissolution of copper from a sulfide; such as chalcocite. According to Velásquez-Yévenes et al. [38], the chloride ions present in the media increase the rate of oxidation of cuprous ions, while Cheng and Lawson [20,39] proposed that the effect of chloride ions promotes the formation of long sulfide crystals that allow the reactants to penetrate the sulfide layer, since in their tests they noticed that, in the absence of chloride ions, the kinetics of dissolution decreased considerably and that covellite did not dissolve. This with time was supported in the research of Nicol and Basson [37], without the presence of chloride ions or with a very low concentration of ions, the potential needed to dissolve covellite is very high.

Figure 4 shows the mean $\mathrm{Cu}$ extraction at different combinations of factor levels. In the interaction time-chloride, the lines are not parallel, and the plot indicates that there is an interaction between the factors. On the other hand, the interaction between time- $\mathrm{H}_{2} \mathrm{SO}_{4}$ and chloride- $\mathrm{H}_{2} \mathrm{SO}_{4}$ is low.

Equation (9) presents the $\mathrm{Cu}$ extraction model over the range of experimental conditions after eliminating the non-significant coefficients.

$$
\% \text { Extraction }=0.47782+0.07472 x_{1}+0.04462 x_{2}+0.01568 x_{3}-0.0163 x_{1}^{2}-0.02546 x_{1} x_{2},
$$

Where $x_{1}, x_{2}$ and $x_{3}$ are codified variables that respectively represent time, chloride and $\mathrm{H}_{2} \mathrm{SO}_{4}$ concentration. 

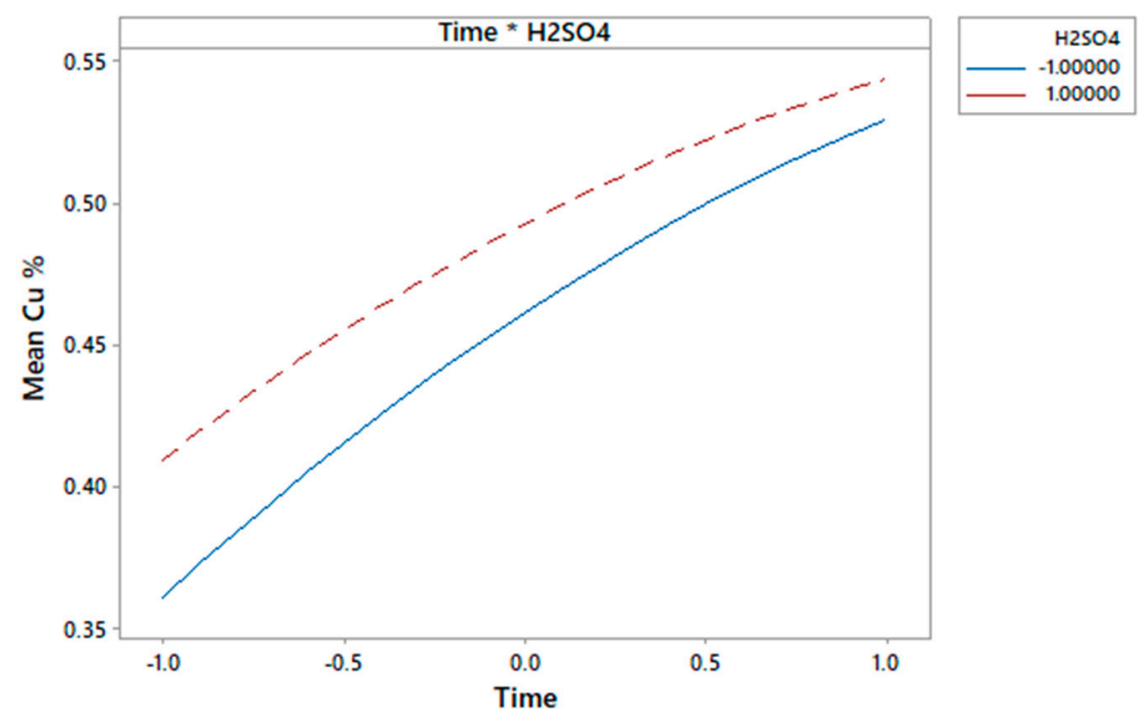

(a)
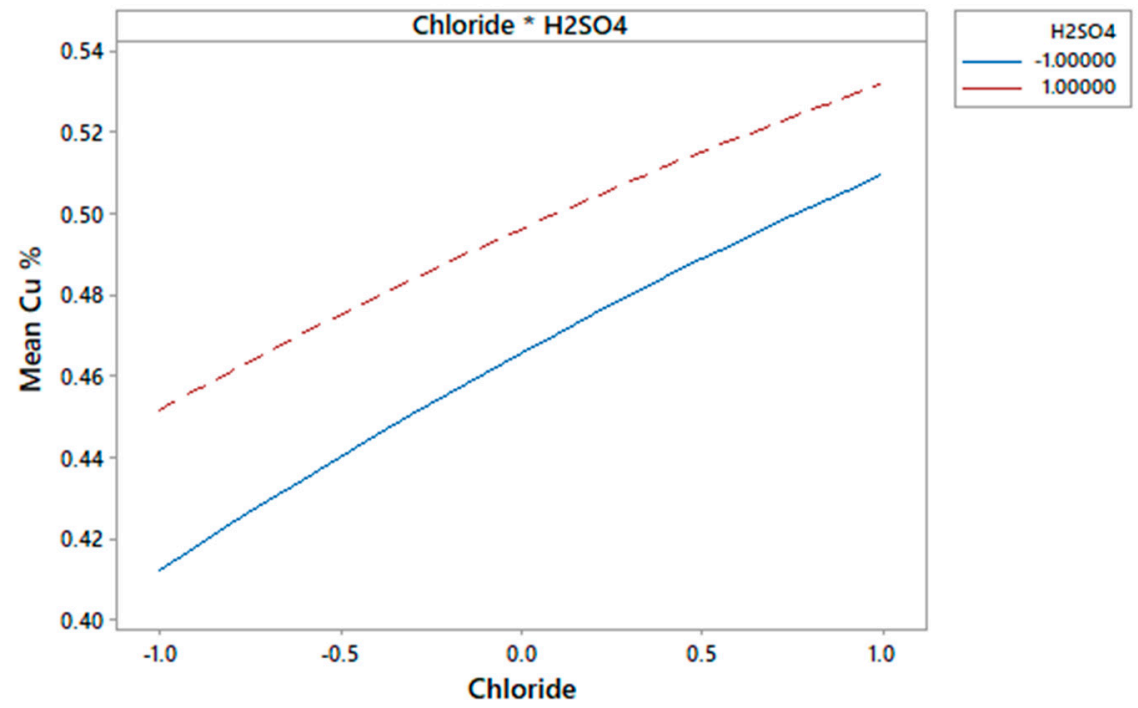

(b)

Figure 4. Interaction effect plot of independent variables Time and $\mathrm{H} 2 \mathrm{SO} 4$ concentration (a); and Chloride and $\mathrm{H} 2 \mathrm{SO} 4$ concentration (b) on the dependent variable $\mathrm{Cu}$ extraction.

An ANOVA test indicated that the quadratic model adequately represented $\mathrm{Cu}$ extraction from $\mathrm{Cu}_{2} \mathrm{~S}$ under the established parameter ranges. The model did not require adjustment and it was validated by the $R^{2}$ value (0.92) and $R^{2}$ adj value (0.90). The ANOVA analysis showed that the factors indicated influence $\mathrm{Cu}$ extraction from $\mathrm{Cu}_{2} \mathrm{~S}$ ( $\mathrm{F}_{\text {Regression }}(22.73)>\mathrm{F}_{\mathrm{T}, 95 \% \text { confidence level }}=\mathrm{F}_{5,21}(2.68)$ ). On the other hand, the p-value of the model (Equation (9)) is lower than 0.05, indicating that the model is statistically significant.

The Mallows's $\mathrm{Cp}=3.62$ (constant +5 predictors) indicated that the model was accurate and did not present bias in estimating the true regression coefficients. This value of $\mathrm{Cp}$ of Mallows allows comparison with other models and establishes that the model found is the one that is most adjustable, due to the $\mathrm{Cp}$ closest to the number of constants and predictors.

In addition, all variance inflation factors (VIF) values are close to one, which ensures that there is no multicollinearity.

It also allows for prediction with an acceptable future forecast margin of error of $R^{2}$ pred $=0.8684$.

Finally, from the adjustment of the ANOVA analysis, it was found that the factors considered, after analysis of the main components, explained the variation in the response. The difference between 
the $R^{2}$ and $R^{2}$ pred of the model was minimal, thus reducing the risk that the model was over adjusted. That means, the probability that the model fits only in the sample data is lower. The ANOVA analysis indicated that time, chloride concentration, $\mathrm{H}_{2} \mathrm{SO}_{4}$ concentration and the interaction of time-chloride are the factors that explain to a greater extent the behavior of the system for the sampled data set.

Table 5 shows that the increase in sulfuric acid concentration does not affect copper dissolution, obtaining similar results under similar conditions of leaching, only a minimum amount of sulfuric acid is needed in the leaching system. This result is consistent with other investigations, since according to Cheng and Lawson [20], a concentration of sulfuric acid of $0.02 \mathrm{~mol} / \mathrm{L}$, is sufficient to perform a leaching of chalcocite and its subsequent phases as it is the djurleite, digenite ore [22]. After this value its effect is null.

On the other hand, it is shown that at a leaching time of $12 \mathrm{~h}$, the values of copper extraction do not vary regardless of the concentration of chloride and sulfuric acid. This could be explained with Equations (4) and (5); Equation (4) is the rapid reaction of the transformation of chalcocite to covellite, in which a low activation energy is required to achieve its transformation [13]. When covellite is formed (Equation (5)), it needs more energy (about $72 \mathrm{~kJ}$ approximately) to achieve its dissolution and later become a copper polysulfide $\left(\mathrm{CuS}_{2}\right)$, what it requires is even more demanding conditions to achieve its complete dissolution [37].

\subsection{Effect on the Chloride Concentration}

It has been known since the 1970s that it is beneficial to work with chloride ions in the leaching of sulfide minerals $[23,40]$. In Figure 5a, when operating at higher chloride concentrations, higher copper recoveries are obtained. When operating with the highest chloride concentrations $(100 \mathrm{~g} / \mathrm{L})$, the highest recovery $(68.82 \%)$ is obtained at $48 \mathrm{~h}$. However, a large difference in copper recoveries cannot be seen when operating at chloride concentrations between 20 and $50 \mathrm{~g} / \mathrm{L}$. At $48 \mathrm{~h}$ and $20 \mathrm{~g} / \mathrm{L}$, a recovery of $63.58 \%$ of $\mathrm{Cu}$ was obtained and for chloride concentrations of $50 \mathrm{~g} / \mathrm{L}, 65.45 \%$ was obtained. On the other hand, in Figure $5 \mathrm{~b}$ it is observed that with the use of waste water $\left(39.16 \mathrm{~g} / \mathrm{L} \mathrm{of}^{-}\right)$, results similar to those presented in Figure 5 a were obtained in a $\mathrm{Cl}^{-}$concentration of $50 \mathrm{~g} / \mathrm{L}$, so it is noted that the presence of calcium ions, fluorine, magnesium and calcium carbonate did not affect the dissolution of copper from the chalcocite. In the tests carried out with seawater, which has approximately a concentration of $20 \mathrm{~g} / \mathrm{L} \mathrm{Cl}^{-}$, obtained copper extractions of up to $63.4 \%$ at $48 \mathrm{~h}$ with a concentration of $0.5 \mathrm{~mol} / \mathrm{L}$ of sulfuric acid. In previous investigations [13,20], it has been determined that leaching is independent of a chloride concentration between 0.5 and $2 \mathrm{~mol} / \mathrm{L}$, but a greater kinetic of dissolution is observed in the first minutes and then the difference decreases as a function of time and behavior similar to that of Figure 5.

Figure 6 shows a residue analysis performed under the conditions of $50 \mathrm{~g} / \mathrm{L} \mathrm{Cl}^{-}$and $0.5 \mathrm{~mol} / \mathrm{L}$ $\mathrm{H}_{2} \mathrm{SO}_{4}$, in a leaching time of $4 \mathrm{~h}$. The result of this XRD is useful to understand the behavior of the chalcocite in a short time and in low reagent conditions, and to observe which mineralogical species are forming. The results show a high formation of synthetic covellite $(77.34 \mathrm{wt} \%)$, early formation of elemental sulfur $(20.20 \mathrm{wt} \%)$ and a remaining chalcocite $(4.46 \mathrm{wt} \%)$, which still does not dissolve. From this, it follows that the transformation of chalcocite to covellite is faster than the transformation of covellite to elemental sulfur, which is similar to that observed in Equations (4) and (5), also, according to Figure 5, the slope of the curve is decreasing slowly, which means less kinetics of copper dissolution as a function of time. In the investigation of Senanayake [28], it is reported that the dissolution of chalcocite in a chloride-iron-water system at $25^{\circ} \mathrm{C}$ occurs at potentials greater than $500 \mathrm{mV}$ with a pH $<4$, while in the research of Miki et al. [13] it is reported that the chalcocite dissolution occurs rapidly at a potential of $500 \mathrm{mV}$ but stops when it reaches $50 \%$ copper extraction. When the potential increases to $550 \mathrm{mV}$, this extraction increases again because once it reaches $50 \%$ copper extraction, the mineral present is mainly covellite, which has a dissolution kinetics lower than the chalcocite and that needs potentials greater than $600 \mathrm{mV}$ to dissolve. 


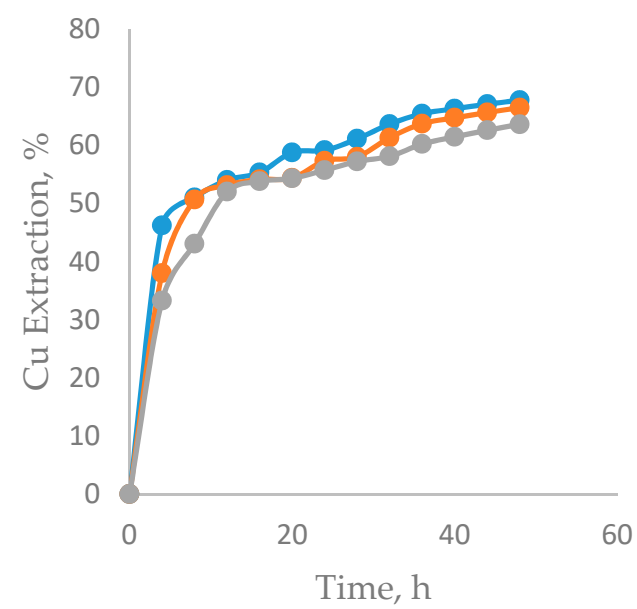

$\rightarrow 100 \mathrm{~g} / \mathrm{L} \longrightarrow 50 \mathrm{~g} / \mathrm{L} \longrightarrow 20 \mathrm{~g} / \mathrm{L}$

(a)

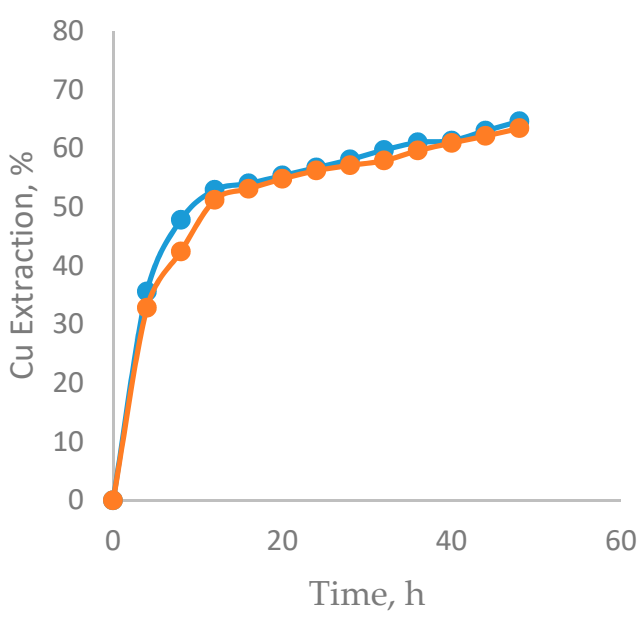

$\longrightarrow$ Waste water $\longrightarrow$ Seawater

(b)

Figure 5. Effect of chloride concentration on Cu extraction from chalcocite $\left(T=25^{\circ} \mathrm{C} \cdot \mathrm{H}_{2} \mathrm{SO}_{4}=0.5 \mathrm{~mol} / \mathrm{L}\right)$; (a) $\mathrm{Cl}^{-}$added by $\mathrm{NaCl}$; (b) $\mathrm{Cl}^{-}$added by waste water and seawater.

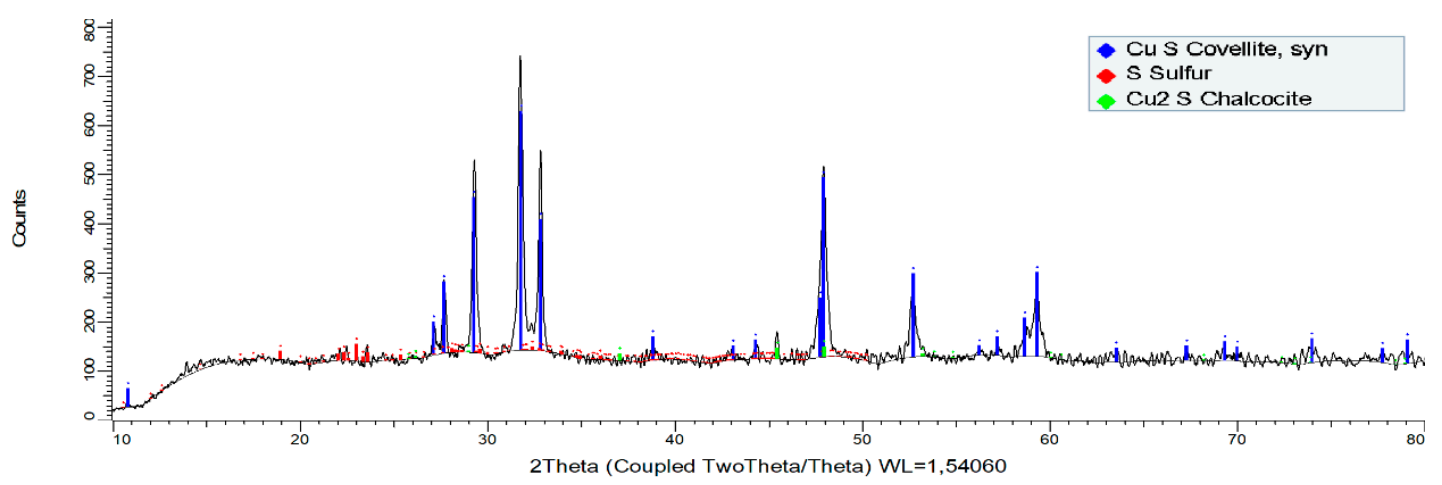

Figure 6. X-ray diffractogram for solid residues (chalcocite mineral) after being leached at $25^{\circ} \mathrm{C}$ in a time of $4 \mathrm{~h}$ with $0.5 \mathrm{~mol} / \mathrm{L} \mathrm{H}_{2} \mathrm{SO}_{4}$ and $50 \mathrm{~g} / \mathrm{L} \mathrm{Cl}^{-}$.

\section{Conclusions}

The present investigation shows the experimental results necessary to dissolve $\mathrm{Cu}$ from a chalcocite mineral in chloride media. The findings of this study were:

1. The linear variables with the greatest influence in the model are: time, chloride concentration and sulfuric acid concentration, respectively.

2. Under normal pressure and temperature conditions, only the chloride-time concentration exerts a significant synergistic effect on the extraction of copper from a chalcocite mineral.

3. The ANOVA analysis indicates that the presented quadratic model is adequate to represent the copper extractions and the value of $R^{2}(0.92)$ validates it.

4. The highest copper extraction is achieved under conditions of low concentration of sulfuric acid $(0.5 \mathrm{~mol} / \mathrm{L})$, high concentrations of chloride $(100 \mathrm{~g} / \mathrm{L})$ and a prolonged leaching time $(48 \mathrm{~h})$ to obtain an extraction of $67.75 \%$ copper.

5. The XRD analysis shows the formation of a stable and non-polluting residue; such as elemental sulfur $\left(\mathrm{S}^{0}\right)$. This residue was obtained in a leaching time of $4 \mathrm{~h}$ at room temperature under conditions of $0.5 \mathrm{~mol} / \mathrm{L} \mathrm{H}_{2} \mathrm{SO}_{4}$ and $50 \mathrm{~g} / \mathrm{L} \mathrm{Cl}^{-}$. 
Author Contributions: N.T. and K.P. contributed in project administration, investigation and wrote paper, W.B. contributed in the data curation and software, M.C. and E.T. contributed in validation and supervision and R.S. and P.H. performed the experiments, review and editing.

Funding: This research received no external funding.

Acknowledgments: The authors are grateful for the contribution of the Scientific Equipment Unit- MAINI of the Universidad Católica del Norte for aiding in generating data by automated electronic microscopy QEMSCAN ${ }^{\circledR}$ and for facilitating the chemical analysis of the solutions. We are also grateful to the Altonorte Mining Company for supporting this research and providing slag for this study, and we thank to Marina Vargas Aleuy and María Barraza Bustos of the Universidad Católica del Norte for supporting the experimental tests.

Conflicts of Interest: The authors declare they have no conflict of interest.

\section{References}

1. Comisión Chilena del Cobre. Sulfuros Primarios: Desafíos y Oportunidades. Registro Propiedad Intelectual $\mathrm{N}^{\circ}$ 2833439. 2017. Available online: https://www.cochilco.cl/ListadoTemtico/sulfurosprimarios_ desafíosyoportunidades.pdf (accessed on 25 April 2019).

2. Navarra, A.; Oyarzun, F.; Parra, R.; Marambio, H.; Mucciardi, F. System dynamics and discrete event simulation of copper smelters. Miner. Metall. Process. 2017, 34, 96-106. [CrossRef]

3. International Copper Study Group. The World Copper Factbook 2017; International Copper Study Group: Lisbon, Portugal, 2017.

4. CESCO. La Minería como plataforma para el desarrollo: Hacia una relación integral y sustentable de la industria minera en Chile. Available online: http://www.cesco.cl/wp-content/uploads/2018/06/ResumenPosition-Paper.pdf (accessed on 12 July 2019).

5. Schlesinger, M.E.; King, M.J.; Sole, K.C.; Davenport, W.G. Extractive Metallurgy of Copper, 5th ed.; Elsevier: Amsterdam, Netherlands, 2011.

6. Oyarzun, R.; Oyarzún, J.; Lillo, J.; Maturana, H.; Higueras, P. Mineral deposits and Cu-Zn-As dispersioncontamination in stream sediments from the semiarid Coquimbo Region, Chile. Environ. Geol. 2007, 53, 283-294. [CrossRef]

7. Dijksira, R.; Senyard, B.; Shah, U.; Lee, H. Economical abatement of high-strength SO2off-gas from a smelter. J. South. African Inst. Min. Metall. 2017, 117, 1003-1007. [CrossRef]

8. Serbula, S.M.; Milosavljevic, J.S.; Radojevic, A.A.; Kalinovic, J.V.; Kalinovic, T.S. Extreme air pollution with contaminants originating from the mining-Metallurgical processes. Sci. Total Environ. 2017, 586, 1066-1075. [CrossRef] [PubMed]

9. Zagoruiko, A.N.; Vanag, S.V. Reverse-flow reactor concept for combined SO2 and co-oxidation in smelter off-gases. Chem. Eng. J. 2014, 238, 86-92. [CrossRef]

10. Baba, A.A.; Balogun, A.F.; Olaoluwa, D.T.; Bale, R.B.; Adekola, F.A.; Alabi, A.G.F. Leaching kinetics of a Nigerian complex covellite ore by the ammonia-ammonium sulfate solution. Korean J. Chem. Eng. 2017, 34, 1133-1140. [CrossRef]

11. Pradhan, N.; Nathsarma, K.C.; Rao, K.S.; Sukla, L.B.; Mishra, B.K. Heap bioleaching of chalcopyrite: A review. Miner. Eng. 2008, 21, 355-365. [CrossRef]

12. Mindat. Copper: The mineralogy of Copper. Available online: https://www.mindat.org/element/Copper (accessed on 8 July 2019).

13. Miki, H.; Nicol, M.; Velásquez-Yévenes, L. The kinetics of dissolution of synthetic covellite, chalcocite and digenite in dilute chloride solutions at ambient temperatures. Hydrometallurgy 2011, 105, 321-327. [CrossRef]

14. Leahy, M.J.; Davidson, M.R.; Schwarz, M.P. A model for heap bioleaching of chalcocite with heat balance: Mesophiles and moderate thermophiles. Hydrometallurgy 2007, 85, 24-41. [CrossRef]

15. Lee, J.; Acar, S.; Doerr, D.L.; Brierley, J.A. Comparative bioleaching and mineralogy of composited sulfide ores containing enargite, covellite and chalcocite by mesophilic and thermophilic microorganisms. Hydrometallurgy 2011, 105, 213-221. [CrossRef]

16. Palencia, I.; Romero, R.; Mazuelos, A.; Carranza, F. Treatment of secondary copper sulphides (chalcocite and covellite) by the BRISA process. Hydrometallurgy 2002, 66, 85-93. [CrossRef] 
17. Xingyu, L.; Biao, W.; Bowei, C.; Jiankang, W.; Renman, R.; Guocheng, Y.; Dianzuo, W. Bioleaching of chalcocite started at different $\mathrm{pH}$ : Response of the microbial community to environmental stress and leaching kinetics. Hydrometallurgy 2010, 103, 1-6. [CrossRef]

18. Ruan, R.; Zhou, E.; Liu, X.; Wu, B.; Zhou, G.; Wen, J. Comparison on the leaching kinetics of chalcocite and pyrite with or without bacteria. Rare Met. 2010, 29, 552-556. [CrossRef]

19. Niu, X.; Ruan, R.; Tan, Q.; Jia, Y.; Sun, H. Study on the second stage of chalcocite leaching in column with redox potential control and its implications. Hydrometallurgy 2015, 155, 141-152. [CrossRef]

20. Cheng, C.Y.; Lawson, F. The kinetics of leaching chalcocite in acidic oxygenated sulphate-chloride solutions. Hydrometallurgy 1991, 27, 249-268. [CrossRef]

21. Herreros, O.; Quiroz, R.; Viñals, J. Dissolution kinetics of copper, white metal and natural chalcocite in $\mathrm{Cl} / \mathrm{Cl}^{-}$media. Hydrometallurgy 1999, 51, 345-357. [CrossRef]

22. Herreros, O.; Viñals, J. Leaching of sulfide copper ore in a NaCl-H2SO4-O2 media with acid pre-treatment. Hydrometallurgy 2007, 89, 260-268. [CrossRef]

23. Senanayake, G. Chloride assisted leaching of chalcocite by oxygenated sulphuric acid via $\mathrm{Cu}(\mathrm{II})-\mathrm{OH}-\mathrm{Cl}$. Miner. Eng. 2007, 20, 1075-1088. [CrossRef]

24. Muszer, A.; Wódka, J.; Chmielewski, T.; Matuska, S. Covellinisation of copper sulphide minerals under pressure leaching conditions. Hydrometallurgy 2013, 137, 1-7. [CrossRef]

25. Ruiz, M.C.; Abarzúa, E.; Padilla, R. Oxygen pressure leaching of white metal. Hydrometallurgy 2007, 86, 131-139. [CrossRef]

26. Petersen, J.; Dixon, D. Principles, mechanisms and dynamics of chalcocite heap bioleaching. In Microbial Processing of Metal Sulfides; Springer: Dordrecht, The Netherlands, 2007; pp. 193-218.

27. Ruiz, M.C.; Honores, S.; Padilla, R. Leaching kinetics of digenite concentrate in oxygenated chloride media at ambient pressure. Metall. Mater. Trans. B Process Metall. Mater. Process. Sci. 1998, 29, 961-969. [CrossRef]

28. Senanayake, G. A review of chloride assisted copper sulfide leaching by oxygenated sulfuric acid and mechanistic considerations. Hydrometallurgy 2009, 98, 21-32. [CrossRef]

29. Tundisi, J.G. Water resources in the future: problems and solutions. Estud. Avançados 2008, 22, 7-16. [CrossRef]

30. Cisternas, L.A.; Gálvez, E.D. The use of seawater in mining. Miner. Process. Extr. Metall. Rev. 2018, 39, 18-33. [CrossRef]

31. MCH. Agua en la Minería. Agua en la Minería. 2018. Available online: https://www.mch.cl/columnas/aguala-mineria/\# (accessed on 3 June 2019).

32. Aguirre, C.L.; Toro, N.; Carvajal, N.; Watling, H.; Aguirre, C. Leaching of chalcopyrite (CuFeS2) with an imidazolium-based ionic liquid in the presence of chloride. Miner. Eng. 2016, 99, 60-66. [CrossRef]

33. Bezerra, M.A.; Santelli, R.E.; Oliveira, E.P.; Villar, L.S.; Escaleira, L.A. Response surface methodology (RSM) as a tool for optimization in analytical chemistry. Talanta 2008, 76, 965-977. [CrossRef]

34. Dean, A.; Voss, D.; Draguljic, D. Response Surface Methodology. In Design and Analysis of Experiments; Springer Texts in Statistics: Cham, Switzerland, 2017; pp. 565-614.

35. Toro, N.; Herrera, N.; Castillo, J.; Torres, C.; Sepúlveda, R. Initial Investigation into the Leaching of Manganese from Nodules at Room Temperature with the Use of Sulfuric Acid and the Addition of Foundry Slag-Part I. Minerals 2018, 8, 565. [CrossRef]

36. Montgomery, D.C. Cap. 3, 6, 7 and 10. In Design and Analysis of Experiments, 8th ed.; Wiley: New York, NY, USA, 2012.

37. Nicol, M.; Basson, P. The anodic behaviour of covellite in chloride solutions. Hydrometallurgy 2017, 172, 60-68. [CrossRef]

38. Velásquez-Yévenes, L.; Nicol, M.; Miki, H. The dissolution of chalcopyrite in chloride solutions: Part 1. The effect of solution potential. Hydrometallurgy 2010, 103, 108-113. [CrossRef]

39. Cheng, C.Y.; Lawson, F. The kinetics of leaching covellite in acidic oxygenated sulphate-chloride solutions. Hydrometallurgy 1991, 27, 269-284. [CrossRef]

40. Dutrizac, J.E. The leaching of sulphide minerals in chloride media. Hydrometallurgy 1992, 29, 1-45. [CrossRef]

(C) 2019 by the authors. Licensee MDPI, Basel, Switzerland. This article is an open access article distributed under the terms and conditions of the Creative Commons Attribution (CC BY) license (http://creativecommons.org/licenses/by/4.0/). 